Review

\title{
Quality of Life (QoL) among Health Care Workers with Diabetes Mellitus: A Literature Review
}

\author{
Warda Alamri *, Aisha Alhofaian (1) and Nahed Mersal
}

check for

updates

Citation: Alamri, W.; Alhofaian, A.; Mersal, N. Quality of Life (QoL) among Health Care Workers with Diabetes Mellitus: A Literature Review. Clin. Pract. 2021, 11, 801-826. https://doi.org/10.3390/ clinpract11040096

Received: 30 September 2021 Accepted: 19 October 2021 Published: 30 October 2021

Publisher's Note: MDPI stays neutral with regard to jurisdictional claims in published maps and institutional affiliations.

Copyright: (c) 2021 by the authors. Licensee MDPI, Basel, Switzerland. This article is an open access article distributed under the terms and conditions of the Creative Commons Attribution (CC BY) license (https:/ / creativecommons.org/licenses/by/ $4.0 /)$.
Department of Medical and Surgical Nursing, Faculty of Nursing, King Abdul Aziz University, P.O. Box. 80209, Jeddah 21589, Saudi Arabia; aalhofaian@kau.edu.sa (A.A.); namali@kau.edu.sa (N.M.)

* Correspondence: wmarzoogalamri@stu.kau.edu.sa; Tel.: +966-566101050

\begin{abstract}
Objective: This scoping literature review explores the impact of diabetes mellitus (DM) on the health-related quality of life (HRQoL) of health care workers (HCWs). HCWs play a vital role in the global health care system, with the COVID-19 pandemic demonstrating their effectiveness and worth beyond any doubt. However, HCWs are among the most vulnerable members of the health care system because they are most susceptible to stress, exhaustion, and occupational health risks. Method: The review was conducted in 2021 and included articles published in English in the past five years that explore diabetic HCWs' QoL and studies intended to assess the relationship between work stress and DM. In total, 27 relevant articles were found that satisfied the inclusion criteria and were critically and thematically analyzed. Results: Most DM studies have focused on the clinical management of patients, but researchers have paid little attention to the high-risk group of HCWs with diabetes. In addition to fulfilling their job mandate, HCWs are burdened with various sociological stressors that affect their QoL. Conclusion: This literature review suggests DM has a significant impact on QoL in the work-life context. However, there is limited evidence to demonstrate the impact of DM on the QoL of HCWs. Thus, further research is needed in this area to improve the provision of integrated care.
\end{abstract}

Keywords: health care workers; diabetes and work; diabetes mellitus; diabetic health care worker; diabetic employee; quality of life

\section{Introduction}

Health care workers (HCWs) constitute a vital component of the global health care system; the COVID-19 pandemic has proved their worth beyond a doubt. HCWs are also the most vulnerable components of the health care system because they are prone to stress, fatigue, and occupational health hazards. This vulnerability often makes them susceptible to various diseases and metabolic disorders such as diabetes mellitus (DM). The preexisting health complications of some HCWs further aggravate their vulnerability to such diseases. The prevalence of DM among HCWs deserves urgent attention in view of the serious health risks DM carries. These health risks can lead to a reduction in quality of life (QoL) and associated psychosocial complications in health care settings [1].

$\mathrm{DM}$ is defined as a group of metabolic disorders characterized by high blood glucose levels, defects in insulin secretion or action, or both. Thus, understanding DM and its complications plays a fundamental role in managing the disease and its spread. Furthermore, patients with proper knowledge of DM and DM complications follow a suitable treatment and health care plan [2].

DM has become a global problem. More than 180 million people have been diagnosed with the disease, and this number is expected to double by 2030. According to the World Health Organization (WHO), DM diagnoses are increasing steadily, and DM has become the seventh leading cause of death [2].

DM is considered a burden on people and countries because it results in renal failure, cardiac problems, vision loss, and limb amputation. It is estimated that approximately 
7 million people have DM, and around 3 million are diagnosed with pre-DM [3]. In terms of DM rate, Saudi Arabia is considered second in the Middle East and seventh in the world.

\subsection{QoL}

There are several approaches to defining QoL. Some approaches depend on human requirements, expectations, subjective well-being, and phenomenological perspectives. In relevant literature, approaches based on objective lists, hedonism, preference satisfaction, life satisfaction, and flourishing are differentiated. Some of the ways in which QoL is defined are "a conscious cognitive judgment of satisfaction with one's life" and "the way an individual perceives their position in life with respect to the culture and value systems in which they live and with respect to their expectations, goals, concerns and standards" [4].

Generic or disease-specific instruments may be used to measure health-related QoL. Generic instruments are widely applicable in different types and intensities of the disease as part of various health interventions and within demographic and cultural subgroups. The purpose of these instruments is to summarize the different health-related QoL (HRQoL) concepts that apply to various impairments, patients, diseases, and populations [5].

Disease-specific measures are those developed to examine particular diagnostic groups or patient populations. These methods are especially valuable when they concentrate on clinically significant changes. Disease-specific HRQoL utility evaluations may be used to perform cost-utility analysis (CUA) so that patients suffering from the same disease can be allocated resources [5].

The following domains are part of two widely used HRQoL measures: role constraints, physical functioning, social functioning, mental health, pain, vitality and mobility, self-care, usual activities, anxiety or depression, and pain or discomfort. These domains help with evaluating self-perceived health status [6].

The methods used to determine HRQoL typically include questions that may be divided into groups (domains or components) developed to examine particular issues that place constraints on health and well-being. Some of the most extensively used instruments for evaluating HRQoL are the World Health Organization Quality of Life Assessment (WHOQOL), the 12-item Short-Form Health Survey (SF-12), and the 36-item Medical Outcomes Study Short Form (SF-36) [7].

In this regard, QoL assessment instruments have played an important part in raising a question regarding the QoL of people suffering from chronic diseases, especially adults. A number of researchers have examined the relationship between chronic diseases and work-related QoL [7]. They found individuals suffering from chronic diseases reported relatively low QoL scores in the physical and/or mental health domains.

\section{2. $D M$ and $Q o L$}

DM is a significant issue in contemporary times. Meanwhile, QoL is a key therapeutic goal in managing the issues that have emerged from the pandemic. Much confusion still exists concerning the QoL context, DM-specific QoL, and HRQoL. Psychometric tools have recently been designed to evaluate QoL, DM-specific QoL, and HRQoL because DM affects the major QoL components. However, there are differences with respect to environment, ethnicity, culture, socioeconomic status, gender, lifestyle habits, profession, and diet [8].

Various factors (e.g., gender, age, physical activity, marital status, duration of DM, and presence of comorbidities) can affect diabetic patients' QoL. Therefore, it is imperative to focus on the QoL assessment of diabetic patients and how various treatment approaches affect patients' QoL [9].

Another study found relatively moderate HRQoL among adult patients suffering from type $2 \mathrm{DM}$ (T2DM) in all domains. In this study, we found the physical domain is the most affected domain. There is a relationship between decreased HRQoL in all domains and overall HRQoL and disease duration, fasting blood sugar, and age. In addition, there is an inverse relationship between (a) overall HRQoL and (b) age, the prevalence of 
documented comorbidity, body mass index (BMI), comorbidities, blood glucose level, and disease duration [10].

Considering the relevance of DM and QoL in the management of long-term conditions, we aim to assess the QoL of HCWs with DM and the general effect of DM on working life in this review.

\section{Materials and Methods}

\subsection{Search Strategies}

In the present review, we began by identifying the appropriate inclusion criteria guided by the population, concept, and context (PCC) framework [11]. These criteria would produce relevant documents to meet the study's objectives (Table 1). First, we identified the PCC to guide the database search process. Then, to identify articles relevant to the literature review, we conducted vigorous research for studies related to the QoL of HCWs, DM prevalence among HCWs, studies intended to assess the relationship between work stress and DM prevalence, and various factors that aggravate or alleviate the disease's symptoms. The search terms included diabetes prevalence in HCWs, QoL among health care workers, diabetes and work, diabetes mellitus, diabetic health care worker, and diabetic employee quality of life. The initial search yielded 1701 studies, out of which we excluded studies that did not focus on DM and work. We included four studies as relevant to HCWs and included 20 studies as more pertinent to the general effect of DM on work and QoL. Out of these, we designated 24 studies for review as specific to DM-related issues among HCWs and employment, as outlined in Figure 1.

Table 1. PCC and Inclusion and Exclusion Criteria.

\begin{tabular}{|c|}
\hline PCC \\
\hline Population: Diabetic HCWs and diabetic employees \\
\hline $\begin{array}{l}\text { Concept: QoL of HCWs, DM prevalence among HCWs, assessment of the relationship between } \\
\text { work stress and DM prevalence, and various factors that aggravate or alleviate the } \\
\text { disease's symptoms }\end{array}$ \\
\hline Context: QoL among diabetic HCWs \\
\hline
\end{tabular}

\subsubsection{Search Engines}

We obtained the articles used in this review from the CINAHL, PubMed, Academic Search Ultimate, and Google Scholar databases using the keywords (search terms) listed in Table 2. The search terms included diabetes prevalence in HCWs, HCWs, DM and work, DM, diabetic HCW, and diabetic employee QoL.

Table 2. Key Search Terms.

\begin{tabular}{c}
\hline Key Search Terms \\
\hline (Diabetes Mellitus) OR (Diabetic Quality of Life) AND (Health Care Worker) OR (Diabetes \\
Mellitus) AND (Employee) OR (Diabetes and Work). \\
\hline
\end{tabular}

\subsubsection{Inclusion and Exclusion Criteria \\ Inclusion Criteria}

The inclusion criteria for the review were literature published between 2015 and 2021; studies, reports, and published articles that focused on QoL of HCWs and DM prevalence among HCWs; studies intended to assess the relationship between work stress and DM and various factors that aggravate or alleviate the disease's symptoms; articles published in the English language; peer-reviewed review articles, including systematic reviews, meta-analyses, and scoping reviews; rapid reviews; and grey literature sources, such as documents from the government and nongovernmental organizations and academic dissertations. 


\section{Exclusion Criteria}

The exclusion criteria were articles not published in the English language and articles published before January 2015.

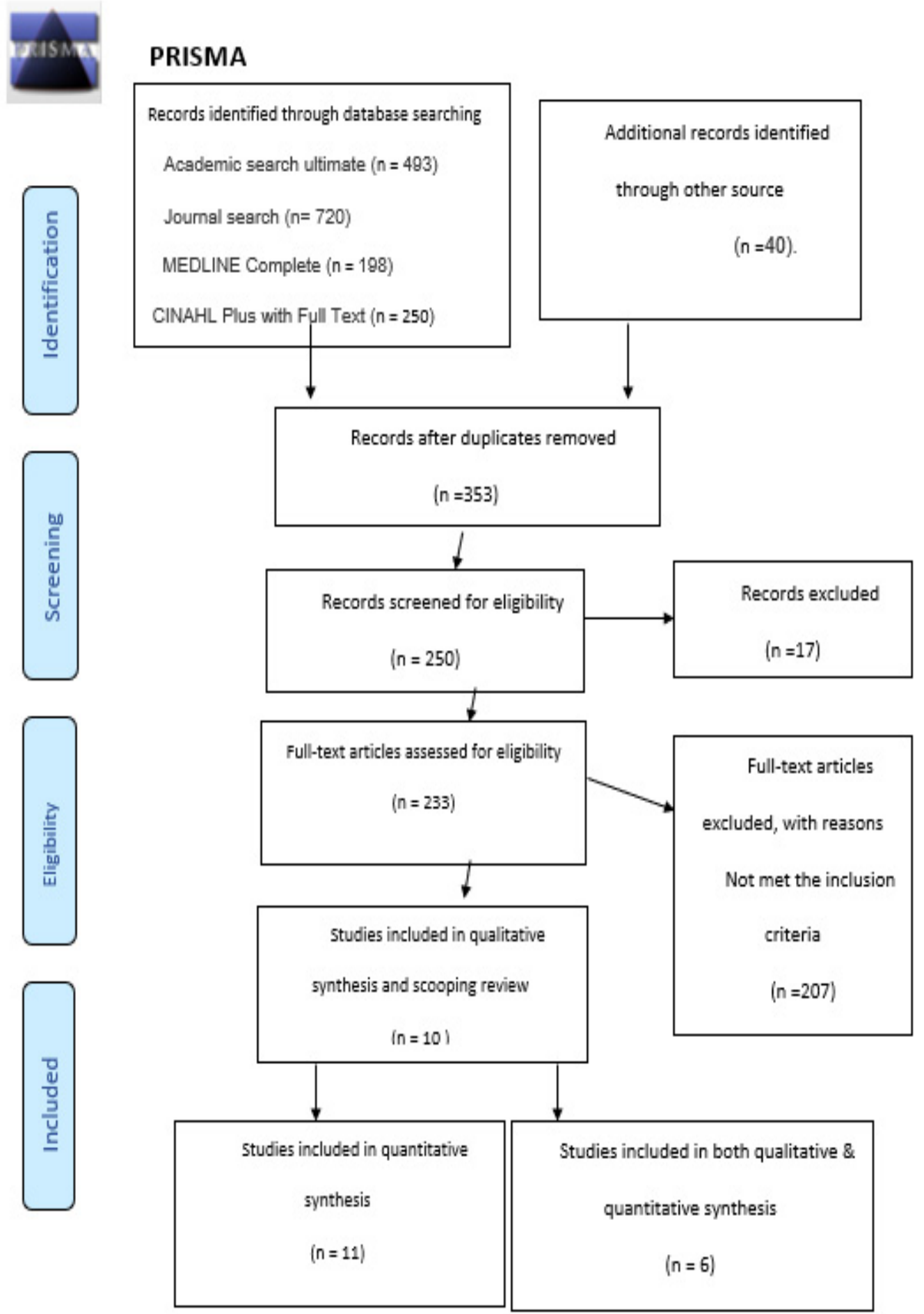

Figure 1. PRISMA Flow Diagram of Included Studies, adapted from Ref. [12].

Finally, we created a thematic framework to guide and sort the existing literature and to collate, summarize, and report the results. 


\subsubsection{Study Selection Process}

We restricted the research criteria to studies conducted from 2015 to 2021. During the initial search, we discovered 1701 articles. We preferred this time restriction because of the need to identify the most recent discussions on the subject. According to the aforementioned inclusion criteria, the studies included keywords and were examined first based on title, then abstract, and then overall content. The flow diagram (Figure 1) is a diagrammatic description of the search process and the criteria for the articles chosen. It summarizes the literature search and article selection process. Finally, we selected 27 of the articles to include in this review.

\subsubsection{Quality Assessment of Included Studies}

Two expert reviewers used the quality scoring system tool formulated by [13], cited in [14], to examine the quality of the studies considered. We included nine components in the evaluation to analyze the research: the title and abstract, introduction and aim, methodology and data sampling, data analysis, bias and ethics, findings, transferability, implications, and utility. Based on the research quality, we classified the scoring as "good", "fair", "poor", or "very poor", with points ranging from 4 for good and 1 for very poor. This generated a minimum score of 9 points and a maximum of 36 points for every study. The definitions given below were used to generate the overall quality grades: high quality (A) with 30-36 points, medium quality (B) with 24-29 points, and low quality (C) with 9-24 points [14]. We conducted the evaluations as depicted in Table A2. In the final quality assessment, we obtained high-quality results in 25 of the studies, medium-quality results in one study, and poor-quality results in one study.

\section{Results}

We will present an explanation of the selected articles in the following subheadings, which will explain each study's characteristics more specifically. All included studies were reviewed separately based on their title, design, sample size, setting, and main finding, as shown in the review matrix in Table A1. The matrix helped us find suitable themes and discuss the selected studies based on the analysis in the literature review presentation section.

The findings from the 27 articles selected for review were reported as main thematic analysis themes and factors that affect diabetic workers' QoL. Because there were few studies about QoL among diabetic HCWs, only two studies deliberately focused on HCWs' QoL, whereas four studies discussed the prevelance of DM among HCWs. Nena et al., 2018 [15] and Muthuri et al., 2021 [16] conducted cross-sectional studies on HCWs' QoL. Coetzee et al., 2019 [17] conducted a retrospective analysis to assess the contribution of traditional and modifiable risk factors to the overall risk and prevalence of T2DM among HCWs in the public sector [18]; the cross-sectional study assessed only the prevalence of DM, hypertension, and obesity among doctors and nurses in a tertiary care medical college hospital in Tamil Nadu, India. Huang et al., 2016 [19] conducted a retrospective and longitudinal study on whether the incidence risk of T2DM between female nurses and female non-nurses differed. Hansen et al., 2016 [20] conducted a cohort study to examine the relationship between shift work and the incidence of DM among Danish nurses.

The remaining 21 studies reviewed the QoL among diabetic patients and the general impact of DM on working life (Table A1). Out of 21 studies, 13 were cross-sectional studies carried out by Manodpitipong et al., 2017 [21], Nakao et al., 2021 [22], Olesen et al., 2020 [23], Seuring et al., 2015 [24], Hansen et al., 2018 [6], Pasmooij et al., 2016 [25], Hakkarainen et al., 2016 [26], Loerbroks et al., 2018 [27], Sonoda et al., 2020 [28], Nielsen et al., 2016 [29], and Tonetto et al., 2019 [30]. A comparative cross-sectional study was carried out by Binesh et al., 2021 [31], whereas Abu et al., 2016 [32] performed a case-control study. A scoping literature review was carried out by Galarraga and Llahana, 2018 [33] in England, whereas Gerbo et al., 2019 [34], Smith et al., 2018 [35], and Imbroll and Cassar, 2021 [36] employed a qualitative exploratory approach. Retrospective cohort 
studies were conducted by Nexø et al., 2020 [37], Ervasti et al., 2015 [38], and Ervasti et al., 2016 [39], whereas McCarthy et al., 2021 [40] used a convergent mixed-method approach to conduct a study in the United States.

Regarding the countries the selected studies focused on, six studies were conducted in Denmark, three in the United Kingdom one in Germany two in the United States, two in Japan, one in Iran, one in Malta one in Egypt, one in Finland, one in Thailand, one in Mexico, one in Taiwan, one in India, two in South Africa, and one in Sweden; the last were conducted in three European regions: northern (Sweden, Denmark), central and western (the Netherlands, Belgium, Germany, Austria, Switzerland, and France), and southern Europe (Italy, Spain, and Greece). One study was conducted in Greece, and one was carried out in Brazil.

Nine articles used a quantitative method, and 10 used a qualitative method. However, two scoping reviews, one systematic review, and six studies used both a qualitative and a quantitative method.

\section{Discussion}

Following the thematic analysis, we found four recurring themes that helped us identify the overall effect of DM on HCWs' QoL and that of diabetic employees in general.

\subsection{QoL among HCWs and Diabetic Patients}

To overcome the challenges in the health care system, improve the quality of care, and increase patient satisfaction with the care received, it is important to know how satisfied HCWs view their QoL and job and what characteristics influence their QoL. This review revealed the overall perception of QoL among HCWs.

As Tonetto et al., 2019 [30] noted, some personal, job-related, and work environment predictors and characteristics are significant predictors of QoL among HCWs. These predictors could be related to HCWs' professional roles, which significantly affect QoL. In their study, nurses reported lower HRQoL scores compared to doctors and occupational safety and health technologists.

Shift work also has a significant impact on QoL. In a study performed in Greece that included 312 employees (87.9\% female), 194 working irregular shifts and 118 on morning shifts, $58.2 \%$ were somewhat or totally dissatisfied with their sleep quality. DM was the most common medical condition that shift workers reported $(p=0.008)$. A comparison of the two groups revealed significant impairment in QoL; in addition, disease duration and frequency, along with employees' age and family status, can have adverse effects on sleep quality [16].

Understanding how DM can compromise a person's QoL enables identification of care needs and thus contributes to improving QoL and control of the disease. The results of the present study suggest the QoL of a person with DM may worsen as care for the disease becomes more complex-QoL tends to worsen as the disease worsens. The results suggest QoL is related to sociodemographic and clinical variables that should be considered in care [15].

\subsection{Overall Risk Factor and Prevalence of DM among HCWs}

The prevalence of DM among doctors and nurses was evaluated by Huang et al., 2016 [19]. The findings showed a $25.4 \%$ prevalence of DM among doctors and $5.6 \%$ among nurses. The findings of Hansen et al., 2016 [20] demonstrated that compared to nonnurses, nurses are at lower risk of developing DM, which may be because of their medical knowledge and educational training. Moreover, nurses undertake health promotion and educational responsibilities.

The same is true with the cohort study conducted in Denmark. Out of 19,873 nurses who worked and were DM-free at recruitment, 837 (4.4\%) developed DM during 15 years of follow-up, with a statistically significant number working the evening or night shifts. 
This demonstrated that night shift nurses were more at risk of developing DM than those working the day shift [21].

Conversely, a study of 260 HCWs with DM in South Africa found 62 nurses (18\%) had hyperglycemia. Therefore, to ensure the well-being of HCWs and society, there is a need to focus on healthy living, learning, and the health risks of obesity [18].

\subsection{Overall Impact of DM on Work and Employee Productivity}

The question of diabetic employees' ability to be productive is essential in work productivity and job satisfaction evaluation. A major contrast was seen between a patient suffering from DM and hypertension in a study by Galarraga and Llahana, 2018 [33], where diabetic patients were found to be more affected with problems such as loss of function, efficiency, and work absenteeism. The job contentment level was low among diabetic patients compared to hypertensive patients because DM seems to lessen a person's work capacity.

A study by Ervasti et al., 2015 [38], in which both men and women were studied individually, showed substantially more Hazard Ratios of sickness leave were seen in both men and women suffering from type 1 DM (T1DM) or T2DM than those without the disease. Although there was no significant difference between those with T1DM and T2DM, men with DM had significantly higher risks of disability pension, unemployment, and sick leave than women.

The benefits received by people suffering from cardiovascular disease (CVD) or DM are linked to early retirement, per long-term research. Another identified reason that leads to quitting work involves greater job requirements alongside fewer benefits. Therefore, it was recommended that optimizing psychosocial work-related factors could be beneficial for people with CVD or DM [26].

This aligns with the outcome of Kouwenhoven-Pasmooij et al., 2016 [25], who found DM indicates a considerably less productive workforce in men and women with DM in Mexico. For this reason, DM has been associated with a fall in the productive workforce and the economy, which suggests DM represents a large burden for people in Mexico. However, a research study performed on six employees and two managers suffering from DM showed their condition had no major adverse effects on their ability to function daily, and they could perform their routine tasks easily; in fact, DM is highly unlikely to impose substantial effects on an individual's ability to pursue a particular career, and the employer is usually unaware of the employee's condition [37].

Hansen et al., 2016 [20] discovered the same. They assessed the working capability of adult diabetic patients and found the results satisfying. Moreover, half the patients reported suffering no adverse effect on their DM self-management. Therefore, it is recommended that social welfare and work-life harmony (e.g., involving diabetic workers in learning programs) can improve working capacities.

Work disability was substantially higher among people with DM (overall mean $=95$ days per year over 7 years, $\mathrm{SD}=143$ ) than among those without $\mathrm{DM}$. In addition, the risk of work disability was slightly higher after DM diagnosis than before and compared with the risk of those without DM [39].

\subsection{Sociodemographic Analysis and Affected QoL Domains 4.4.1. Sociodemographic Analysis}

Age and obesity are major sociodemographic factors that contribute to DM. Huang et al., 2016 [19] found the prevalence of obesity was 15.1\% among doctors and 3.2\% among nurses, which was found to be statistically significant. In addition, the crucial factors of the risk of DM occurrence in nurses are age and the Charlson Comorbidity Index (CCI) scale, which predicts the 10-year survival rate for patients with multiple comorbidities, as discovered by Hansen et al., 2016 [20].

Shift work can be one of the main reasons for increased incidence of DM, according to Manodpitipong et al., 2017 [21]. They found no evidence of an interaction between 
night-shift work and BMI, which suggests that in terms of DM risk from shift work, weight gain was more common among nurses working night shifts than day shifts. One of the main reasons for weight gain attributed to night-shift work is that excessive secretion of cortisol and interleukins, together with increased insulin concentrations, can lead to abdominal fat buildup, lipid disorders, and insulin resistance.

Furthermore, various other factors can lead to obesity; these include bad diet and inadequate sleep from working night shifts, as identified by Nakao et al., 2021 [22]. They found that patients with T2DM have excessive BMIs. Per the HbA1c estimate, they had poor glycemic control compared with participants working day shifts or unemployed participants.

In addition, work schedules, including rotating shifts, can affect the timing of medications and nutritional intake, thus making it more challenging for individuals to effectively manage the condition. Moreover, time away from work may be necessary for medical appointments or illness [35].

In one study, half of the participants, who were 55 years or older $(47 \%)$, were ranked in the highest-risk group, and $37 \%$ of the participants in the high-risk group were older than 55 years [16]. Increasing age adversely affects lifestyle choices, work status, and health, especially among women [31].

In their study, Ervasti et al., 2015 [38] found workers with DM in Sweden were more likely to have other risk factors of work disability and leave absence, including older age, a lower education level, and comorbid conditions, than those without DM. DM risks for employees increase at age 44 and are greater for both men and women [23].

\subsubsection{Affected QoL Domains}

According to [41], there are eight QoL domains: physical functioning (PF), physical role limitations (PL), bodily pain (BP) energy/vitality (VT), general health perceptions $(\mathrm{GH})$, social functioning (SF), emotional role limitations (RE), and mental health (MH).

In this review, we found the most common QoL domains affected were predominantly related to physical health, emotional well-being (particularly anxiety and occupational stress), and social functioning. Compared to the general population, adults with T1DM experienced lower health-related QoL [31].

Diabetic workers face multiple challenges every workday-diet, exercise, and patient education. Furthermore, the treatment of individuals with T1DM, with its total dependence on exogenous insulin, includes injections of basal and prandial insulin or continuous subcutaneous insulin infusion. In addition, work schedules, especially rotating shifts, can affect the timing of medications and nutritional intake, thus making it more challenging for individuals to effectively manage the condition. Time away from work may be necessary for medical appointments or illness [35]. Of 140 employees with DM aged over 40 years, $12(8.6 \%)$ were unable to attend their appointments and were considered the dropout group of outpatients [29].

Many factors lead to people quitting their jobs and taking disability allowances, including excessive and physical workload requirements. However, this is more common in employees with DM or CVD [24], which highlights the importance of assistance and training from management at work. For example, using adjustable working arrangements and timing schedules to align with employees' well-being are essential to improving work efficiency [37].

According to [6], young people with T1DM experience a great deal of presure and find it difficult to manage their condition because of their higher work demand. Thus, this may interfere with their DM management. In the same study, a participant confessed that because of his workload, he does not focus on his DM management and skips his breaks-actions that can lead to a further increase in stress levels.

According to [27], when work requirements go beyond an individual's resources for managing their work, they may experience work-related stress-a major cause of burnoutdepression, and anxiety. Furthermore, anxiety, depression, burnout, and low working capacity have been linked to self-admitted fatigue. Anxiety is an important comorbidity 
factor to be considered in people with DM, although the systematic review indicated DM may not be associated with an increased risk of incident anxiety [36]. However, there is still evidence that anxiety is associated with poorer outcomes in people with DM, such as poorer glycemic control, worsened functioning, and increased DM complications.

There is a significant relationship between changing shift patterns and nighttime shifts and having T2DM. The relationship is often characterized by poor glycemic control that is rarely found in people who do not work in shifts [20]. Changing shift patterns affect eating and sleeping patterns, thus altering blood glucose levels, disturbing circadian rhythms, and causing a reduction in insulin sensitivity that further increases problems in daily routines [23].

Psychosocial factors trigger stress-associated hormonal pathways, which then disturb DM management and glucose metabolism and alter lifestyle. The psychosocial factors that affect the clinical and social results of DM include psychological strain, job stress, and social support [40].

One of the challenges that employees with DM face every workday is the tension between the worker's logic and the patient's logic. According to Hansen et al., 2018 [6], a participant said she "has accepted that she avoided taking insulin at her work due to the tasks' uncertainty at her work[;] she considered it a safer option to have high levels of glucose in her blood rather than going through hypoglycemia at her work place where children are involved".

T1DM patients develop work-related stress like any other worker, although theirs is usually compounded by the stress of self-managing the disease [27]. Agreeing with this observation, McCarthy et al., 2021 [40] found people with DM often go through work with a disability, which has been linked to psychological distress.

Distress has been linked to biopsychological factors associated with occupational balance in people with DM. An increasing level of distress is associated with lower occupational balance and poorer glycemic control among diabetic employees [32]. Seuring et al., 2015 [24] found that compared with other working populations, an overall poor psychological working atmosphere has been noted in employees with T2DM.

Moreover, many studies mentioned the effectiveness of work-related support and social support in creating better work-life balance for diabetic workers. Additionally, keeping shift patterns and hours in mind when offering time management support to diabetic workers is essential; this could enhance workers' QoL and work capabilities and better their work-life balance. In terms of work-related factors, one study [29] found greater supervisor support (emotional and physical support) was associated with a lower risk for dropping out of outpatient visits for DM treatment among Japanese male employees with DM.

\section{Gap and Limitations of the Included Literature}

By reviewing the literature, we found some limitations with the search strategy when applying keywords (the search terms) as a result of limited studies, systematic reviews, and meta-analyses conducted on this topic globally and locally in Saudi Arabia. To the best of our knowledge, this review is one of few exhaustive reviews. However, we included studies related only to HCWs. The second limitation is the search scope; we focused on recent studies. With these limitations, we cannot generalize findings and draw concrete conclusions for recommendations.

\section{Summary}

The main purpose of this scoping review was to identify an overview regarding the QoL of HCWs with DM. There have been limited studies, systematic reviews, and meta-analyses conducted on this topic globally, but we believe this review is exhaustive.

After thematic analysis, we found age and obesity were the major sociodemographic factors contributing to DM. Furthermore, we found emotional wellness, physical well-being, and social performance (particularly anxiety and occupational stress) are the primarily 
influenced QoL domains. Although the overall impact of DM on work productivity was significantly high, the job satisfaction score was relatively low, and work absenteeism was incredibly high. In addition, work productivity loss and impairment were more common among diabetic employees.

However, intervening with social support, providing work-life balance, and involving diabetic workers in educational programs are strategic efforts that occupational health staff can use to avoid the aforementioned problems. Additionally, keeping shift patterns and hours in mind when offering time management support to diabetic employees is essential because doing so can enhance their QoL and work capabilities.

Author Contributions: Conceptualization, A.A. and W.A.; methodology, N.M.; software, W.A.; validation, A.A., W.A. and N.M.; formal analysis, A.A.; investigation, W.A.; resources, N.M.; data curation, W.A.; A.A. writing original draft preparation, W.A.; writing review and editing, A.A.; visualization, N.M.; supervision, A.A.; project administration, A.A.; funding acquisition, W.A. All authors have read and agreed to the published version of the manuscript.

Funding: This research received no external funding.

Institutional Review Board Statement: Not applicable.

Informed Consent Statement: Not applicable.

Data Availability Statement: Not applicable.

Conflicts of Interest: The authors declare no conflict of interest. 
Appendix A.

Table A1. Literature Review Matrix.

\begin{tabular}{|c|c|c|c|c|c|}
\hline $\begin{array}{c}\text { Author(s)/ } \\
\text { Year of Publication }\end{array}$ & $\begin{array}{l}\text { Research } \\
\text { Setting(s) }\end{array}$ & Tool(s) Used & Study Group(s) & Methodology & Result(s) \\
\hline $\begin{array}{l}\text { (1) Ankia Coetzee, Amanda } \\
\text { Beukes, Reinhardt Dreyer, } \\
\text { Salaamah Solomon, } \\
\text { Lourentia van Wyk, Roshni } \\
\text { Mistry, Magda Conradie, } \\
\text { and Mari van de Vyver, } \\
\text { published in } 2019 \text { [17] }\end{array}$ & $\begin{array}{l}\text { Tygerberg } \\
\text { Hospital, } \\
\text { Cape Town, } \\
\text { South Africa }\end{array}$ & $\begin{array}{l}\text { Test2Prevent and risk } \\
\text { stratification }\end{array}$ & $\begin{array}{l}\text { All health care } \\
\text { workers (HCWs) } \\
\text { at Tygerberg } \\
\text { Hospital }\end{array}$ & $\begin{array}{l}\text { A retrospective analysis } \\
\text { was performed on data } \\
\text { obtained from } 260 \\
\text { participants. }\end{array}$ & $\begin{array}{l}\text { Education, lifestyle, and overweight interventions are of paramount } \\
\text { importance to ensure the metabolic health of HCWs and their } \\
\text { communities. Policies and guidelines focused on limiting } \\
\text { unhealthy / obesogenic work environments are urgently needed. } \\
\text { The prevalence of known hyperglycemia in this cohort is concerning } \\
(11 \%, n=62) \text {. An additional } 29 \text { HCWs were identified as at high risk of } \\
\text { developing type } 2 \text { diabetes mellitus (T2DM) within } 10 \text { years. } \\
\text { Consumption of sugar-sweetened beverages and minimal physical } \\
\text { activity were identified as modifiable intervention targets. }\end{array}$ \\
\hline $\begin{array}{l}\text { (2) Shailendra Kumar B. } \\
\text { Hegde, S. } \\
\text { Sathiyanarayanan, Sathiya } \\
\text { Narayanan, Sanjana } \\
\text { Venkateshwaran, Akshaya } \\
\text { Sasankh and P. } \\
\text { Ganeshkumar, Balaji } \\
\text { Ramraj, published in } \\
\text { 2015 [18] }\end{array}$ & $\begin{array}{l}\text { Tamil Nadu, } \\
\text { India }\end{array}$ & $\begin{array}{l}\text { Case record form } \\
\text { developed }\end{array}$ & $\begin{array}{l}\text { Doctors and } \\
\text { nurses aged } \\
18-65 \text { years } \\
\text { working at a } \\
\text { tertiary care } \\
\text { medical college }\end{array}$ & $\begin{array}{l}\text { This was a cross-sectional } \\
\text { study; the study period was } \\
\text { June-August } 2013 .\end{array}$ & $\begin{array}{l}\text { The prevalence of diabetes mellitus (DM) was found } \\
\text { to be significantly higher among doctors } \\
\text { ( } 25.4 \%) \text { than nurses (5.6\%). In addition, } \\
\text { the prevalence of hypertension was found to be } \\
\text { significantly higher among doctors (29.4\%) than nurses }(13.7 \%) \text {. } \\
\text { Other factors such as age and obesity were covered. }\end{array}$ \\
\hline $\begin{array}{l}\text { (3) Hsiu-Ling Huang, } \\
\text { Cheng-Chin Pan, Shun-Mu } \\
\text { Wang, Pei-Tseng Kung, } \\
\text { Wen-Yu Chou, and } \\
\text { Wen-Chen Tsai, published } \\
\text { in 2016 [19] }\end{array}$ & $\begin{array}{l}\text { National } \\
\text { Health } \\
\text { Insurance } \\
\text { Research } \\
\text { Database, } \\
\text { Taiwan }\end{array}$ & $\begin{array}{l}\text { Modified Charlson } \\
\text { Comorbidity Index } \\
\text { (CCI) }\end{array}$ & Nurses & $\begin{array}{l}\text { A retrospective and } \\
\text { longitudinal method was } \\
\text { adopted in this study, and } \\
\text { data were sourced. To } \\
\text { comply with privacy } \\
\text { measures, personal } \\
\text { information was removed } \\
\text { from the collected data. } \\
\text { Study data were obtained } \\
\text { from the Longitudinal } \\
\text { Health Insurance Research } \\
\text { Database, and nurses were } \\
\text { sampled from the Registry } \\
\text { for Medical Personnel. }\end{array}$ & $\begin{array}{l}\text { The authors found found age and CCI serve as critical factors that } \\
\text { influence DM development risks among nurses. The low degree of } \\
\text { DM development among the nurses may be attributable to the fact } \\
\text { that nurses possess substantial knowledge on health care and on } \\
\text { healthy behaviors. The results of this study can be used as a reference } \\
\text { to assess occupational risks facing nursing staff, to prevent DM } \\
\text { development, and to promote health education. }\end{array}$ \\
\hline
\end{tabular}


Table A1. Cont..

\begin{tabular}{|c|c|c|c|c|c|}
\hline $\begin{array}{c}\text { Author(s)/ } \\
\text { Year of Publication }\end{array}$ & $\begin{array}{l}\text { Research } \\
\text { Setting(s) }\end{array}$ & Tool(s) Used & Study Group(s) & Methodology & Result(s) \\
\hline & & & & $\begin{array}{l}\text { Nurses and non-nurses } \\
\text { with similar traits and } \\
\text { health conditions were } \\
\text { selected via one-to-one } \\
\text { propensity score matching. } \\
\text { A total of } 111,670 \text { subjects } \\
\text { were selected ( } 55,835 \text { nurses } \\
\text { and } 55,835 \text { non-nurses). }\end{array}$ & \\
\hline $\begin{array}{l}\text { (4) Ulla Møller Hansen, } \\
\text { Bryan Cleal, Ingrid } \\
\text { Willaing, and Tine } \\
\text { Tjørnhøj-Thomsen, } \\
\text { published in } 2018 \text { [6] }\end{array}$ & $\begin{array}{l}\text { Diabetes Clinic } \\
\text { of the Danish } \\
\text { Denmark }\end{array}$ & $\begin{array}{l}\text { In-depth interview as } \\
\text { the method of inquiry }\end{array}$ & $\begin{array}{l}\text { Employees with } \\
\text { type } 1 \text { diabetes } \\
\text { mellitus (T1DM) }\end{array}$ & $\begin{array}{l}\text { A total of } 40 \text { interviews } \\
\text { were conducted using the } \\
\text { Atkinson analysis. The first } \\
\text { phase was within-case } \\
\text { analysis; the second phase } \\
\text { was theory-based analysis. } \\
\text { During the third phase, we } \\
\text { refined the analysis. }\end{array}$ & $\begin{array}{l}\text { Managing T1DM in work-life may be articulated as a matter of } \\
\text { containment: the assemblage of practices and mental and emotional } \\
\text { work aimed at keeping DM at the level of a side involvement. } \\
\text { Workers with T1DM face tension between the worker's and patient's } \\
\text { competing logics, which temporality heavily influences. }\end{array}$ \\
\hline
\end{tabular}


Table A1. Cont. .

\begin{tabular}{|c|c|c|c|c|c|}
\hline $\begin{array}{c}\text { Author(s)/ } \\
\text { Year of Publication }\end{array}$ & $\begin{array}{l}\text { Research } \\
\text { Setting(s) }\end{array}$ & Tool(s) Used & Study Group(s) & Methodology & Result(s) \\
\hline $\begin{array}{c}\text { (6) T.A. } \\
\text { Kouwenhoven-Pasmooij, } \\
\text { Alex Burdorf, J.W. Jolien } \\
\text { Roos-Hesselink, M.G.M. } \\
\text { Hunink and. S.J.W. } \\
\text { Robrock, } \\
\text { published in 2016 [25] }\end{array}$ & $\begin{array}{l}\text { Three } \\
\text { European } \\
\text { regions: } \\
\text { northern } \\
\text { (Sweden and } \\
\text { Denmark), } \\
\text { central and } \\
\text { western (the } \\
\text { Netherlands, } \\
\text { Belgium, } \\
\text { Germany, } \\
\text { Austria, } \\
\text { Switzerland, } \\
\text { and France), } \\
\text { and southern } \\
\text { Europe (Italy, } \\
\text { Spain, and } \\
\text { Greece) }\end{array}$ & $\begin{array}{l}\text { Survey of Health and } \\
\text { Retirement in Europe } \\
\text { (SHARE) }\end{array}$ & $\begin{array}{l}\text { Employees with } \\
\text { cardiovascular } \\
\text { disease (CVD) } \\
\text { and/or DM }\end{array}$ & $\begin{array}{l}\text { Longitudinal survey of } \\
5182 \text { employees }\end{array}$ & $\begin{array}{l}\text { The results of this longitudinal study showed that having CVD or DM } \\
\text { is associated with early exit from paid work through disability benefits } \\
\text { or early retirement, and having low rewards or high job demands with } \\
\text { low control further increased this probability. } \\
\text { It showed that optimizing psychosocial work-related factors could be } \\
\text { beneficial in people with CVD or DM. }\end{array}$ \\
\hline $\begin{array}{l}\text { (7) Sofia Llahana and } \\
\text { Michele Miranda Galarraga, } \\
\text { published in } 2018 \text { [33] }\end{array}$ & $\begin{array}{l}\text { University } \\
\text { College } \\
\text { London, } \\
\text { England }\end{array}$ & $\begin{array}{l}\text { Scoping literature } \\
\text { review }\end{array}$ & $\begin{array}{l}\text { The career QoL } \\
\text { of adults with } \\
\text { T2DM }\end{array}$ & $\begin{array}{l}\text { The review was conducted in } \\
\text { February } 2015 \text { and included } \\
\text { articles published in English } \\
\text { in the past } 10 \text { years exploring } \\
\text { career quality of life (QoL). } \\
\text { Five articles satisfied the } \\
\text { inclusion criteria and were } \\
\text { critically and thematically } \\
\text { analyzed. }\end{array}$ & $\begin{array}{l}\text { Evidence suggests emotional well-being is the QoL domain that T2DM } \\
\text { affects most, with depression and anxiety being reported as the most } \\
\text { common issues. Additional domains were social functioning and } \\
\text { economic burden. Sociodemographic and cultural differences were } \\
\text { identified as variables that can influence a career's QoL. This literature } \\
\text { review suggests T2DM in adults has a significant impact on their } \\
\text { career's QoL; however, there is limited evidence to demonstrate how } \\
\text { health care professionals can support careers, so further research is } \\
\text { needed in this area to improve the provision of integrated care. }\end{array}$ \\
\hline
\end{tabular}


Table A1. Cont..

\begin{tabular}{|c|c|c|c|c|c|}
\hline $\begin{array}{c}\text { Author(s)/ } \\
\text { Year of Publication }\end{array}$ & $\begin{array}{l}\text { Research } \\
\text { Setting(s) }\end{array}$ & Tool(s) Used & Study Group(s) & Methodology & Result(s) \\
\hline $\begin{array}{l}\text { (8) Areesa Manodpitipong, } \\
\text { Sunee Saetung, Hataikarn } \\
\text { Nimitphong, Nantaporn } \\
\text { Siwasaranond, Thanawat } \\
\text { Wongphan, Chotima } \\
\text { Sornsiriwong, Pranee } \\
\text { Luckanajantachote, } \\
\text { Prasitchai Mangjit, Prasit } \\
\text { Keesukphan, Stephanie J. } \\
\text { Crowley, Megan M. Hood, } \\
\text { and Sirimon Reutrakul, } \\
\text { published in 2017 [21] }\end{array}$ & $\begin{array}{l}\text { Ramathibodi } \\
\text { Hospital, } \\
\text { Mahidol } \\
\text { University, } \\
\text { Bangkok, } \\
\text { Thailand }\end{array}$ & $\begin{array}{l}\text { Depressive symptoms } \\
\text { were assessed using } \\
\text { the Thai version of the } \\
\text { Center for } \\
\text { Epidemiologic } \\
\text { Studies-Depression } \\
\text { Scale. } \\
\text { We used the modified } \\
\text { Pittsburgh Sleep } \\
\text { Quality Index (PSQI) } \\
\text { score to assess sleep } \\
\text { quality independently } \\
\text { of sleep duration. } \\
\text { Morningness- } \\
\text { eveningness } \\
\text { preference was } \\
\text { assessed using the } \\
\text { validated Thai version } \\
\text { of the composite } \\
\text { morningness score. } \\
\text { Participants were } \\
\text { interviewed regarding } \\
\text { their dietary intake } \\
\text { from the previous day } \\
\text { (24-h dietary recall). }\end{array}$ & $\begin{array}{l}\text { A total of } 249 \\
\text { adult } \\
\text { participants } \\
\text { with T2DM who } \\
\text { worked night } \\
\text { shifts in six } \\
\text { hospitals in } \\
\text { Thailand were } \\
\text { invited to } \\
\text { participate. }\end{array}$ & $\begin{array}{l}\text { We compared glycemic } \\
\text { control in patients with } \\
\text { T2DM who were performing } \\
\text { night-shift work compared } \\
\text { with those who were } \\
\text { non-shift workers and those } \\
\text { who were unemployed. Sleep } \\
\text { duration, sleep quality, and } \\
\text { dietary intake were examined } \\
\text { as potential confounders. In } \\
\text { addition, } \\
\text { morningness-eveningness } \\
\text { preference, previously } \\
\text { reported to be related to } \\
\text { worse glucose control in } \\
\text { patients with T2DM, was } \\
\text { considered. }\end{array}$ & $\begin{array}{l}\text { Night-shift work is associated with poorer glycemic control in patients } \\
\text { with T2DM. Thus, reducing the adverse metabolic effects of circadian } \\
\text { misalignment may help improve glycemic control in this patient group. } \\
\text { We found night-shift workers had higher body mass index (BMI) than } \\
\text { unemployed participants }\end{array}$ \\
\hline
\end{tabular}

(9) Pirjo Hakkarainen, Leena Moilanen, Vilma Hänninen, Jarmo

Heikkinen, and Kimmo Räsänen, published in 2016 [26]
The University of Eastern

Finland and the Kuopio

University

Hospital,

Finland
The questionnaire was constructed based on previously validated work-life scales and DM questionnaires.
This was a cross-sectional study. The questionnaire was mailed to a random sample of 2500 Finns with T1DM aged 18-65 years and drawn from the Medication

Reimbursement Register of the Social Insurance

Institution of Finland; 767 respondents were included in
Work-related DM distress was found to be common among workers with T1DM. Problems with physical work conditions, work ability, difficulty in accepting DM, job demands, and depressive symptoms proved to be associated with work-related DM distress. the analysis. 
Table A1. Cont..

\begin{tabular}{|c|c|c|c|c|c|}
\hline $\begin{array}{c}\text { Author(s)/ } \\
\text { Year of Publication }\end{array}$ & $\begin{array}{l}\text { Research } \\
\text { Setting(s) }\end{array}$ & Tool(s) Used & Study Group(s) & Methodology & Result(s) \\
\hline $\begin{array}{l}\text { (10) Mahmoud E. Abu } \\
\text { Salema, Nagwa N. Hegazy, } \\
\text { and Shaimaa G. Mohamed, } \\
\text { published in } 2016 \text { [32] }\end{array}$ & $\begin{array}{l}\text { The urban area } \\
\text { was the } \\
\text { primary health } \\
\text { care unit of } \\
\text { Shebin } \\
\text { EL-Kom City, } \\
\text { Shebin District, } \\
\text { Menoufia } \\
\text { Governorate. } \\
\text { The rural area } \\
\text { was the } \\
\text { primary health } \\
\text { care unit of } \\
\text { Batanon } \\
\text { Village, Shebin } \\
\text { EL-Kom } \\
\text { District, } \\
\text { Menoufia } \\
\text { Governorate, } \\
\text { Egypt }\end{array}$ & $\begin{array}{l}\text { Arabic-validated } \\
\text { version of work } \\
\text { productivity and } \\
\text { impairment, the } \\
\text { general health version } \\
\text { (WPAI: GH), and job } \\
\text { satisfaction } \\
\text { questionnaire }\end{array}$ & $\begin{array}{l}\text { Nurses and } \\
\text { midwives }\end{array}$ & $\begin{array}{l}\text { This was a case-control } \\
\text { cross-sectional study. A total } \\
\text { of } 800 \text { participants were } \\
\text { recruited ( } 400 \text { patients and } \\
400 \text { controls). They were } \\
\text { enrolled from urban and } \\
\text { rural family health units as } \\
\text { follows: } 223 \text { DM patients, } 177 \\
\text { hypertensive patients, and } \\
400 \text { control } \\
\text { group participants. }\end{array}$ & $\begin{array}{l}\text { Work absenteeism, work productivity loss, and work impairment were } \\
\text { more prominent with diabetic patients than with hypertensive patients. } \\
\text { There was a statistically significant difference between the studied } \\
\text { groups and job satisfaction; the job satisfaction score was lower for } \\
\text { diabetic patients than for hypertensive patients. } \\
\text { DM appears to reduce an individual's ability to work more than } \\
\text { hypertension does. }\end{array}$ \\
\hline $\begin{array}{l}\text { (11) Claire Farrugia Imbroll } \\
\text { and Maria Cassar, } \\
\text { published in } 2021 \text { [36] }\end{array}$ & $\begin{array}{l}\text { University of } \\
\text { Malta, Malta }\end{array}$ & $\begin{array}{c}\text { Semi-structured, } \\
\text { face-to-face, } \\
\text { individual interviews } \\
\text { were conducted. The } \\
\text { sample consisted of } \\
\text { six employees and } \\
\text { two managers of an } \\
\text { organization based } \\
\text { in Malta. }\end{array}$ & $\begin{array}{c}\text { Employees with } \\
\text { DM }\end{array}$ & $\begin{array}{l}\text { A qualitative exploratory } \\
\text { approach using one-to-one } \\
\text { interviews was adopted. } \\
\text { Thematic analysis was used } \\
\text { to analyze the data, which } \\
\text { was carried out in keeping } \\
\text { with Miles and } \\
\text { Huberman's model. }\end{array}$ & $\begin{array}{l}\text { We explored the supports and challenges that adults with DM } \\
\text { experience when fulfilling their employment commitments. We hope } \\
\text { the findings will contribute to enhancing employees' experience with } \\
\text { DM at their workplace as well as inform employers and guide } \\
\text { policy development. }\end{array}$ \\
\hline
\end{tabular}


Table A1. Cont..

\begin{tabular}{|c|c|c|c|c|c|}
\hline $\begin{array}{c}\text { Author(s)/ } \\
\text { Year of Publication }\end{array}$ & $\begin{array}{l}\text { Research } \\
\text { Setting(s) }\end{array}$ & Tool(s) Used & Study Group(s) & Methodology & Result(s) \\
\hline $\begin{array}{l}\text { (12) Jenniy Ervasti, Mika } \\
\text { Kivimäki, } \\
\text { RosemaryDray-Spira, John } \\
\text { Head, Marcel Goldberg, } \\
\text { Janna Pentti, Markus Jokela, } \\
\text { Jonnas Vahtera, Marie Zins } \\
\text { and Matti Virtanen, } \\
\text { published in } 2015 \text { [39] }\end{array}$ & $\begin{array}{l}\text { Finnish } \\
\text { Institute of } \\
\text { Occupational } \\
\text { Health, UK }\end{array}$ & $\begin{array}{l}\text { The study used } \\
\text { standard } \\
\text { questionnaires, and } \\
\text { study-specific } \\
\text { estimates were pooled } \\
\text { using fixed-effects } \\
\text { meta-analysis. }\end{array}$ & $\begin{array}{c}\text { Employees with } \\
\text { DM }\end{array}$ & $\begin{array}{c}\text { The study involved a pooled } \\
\text { analysis of } \\
\text { individual-participant data } \\
\text { from three occupational } \\
\text { cohort studies (the Finnish } \\
\text { Public Sector Study, the } \\
\text { British Whitehall II Study, } \\
\text { and the French GAZEL } \\
\text { Study). A total of 1,088 } \\
\text { women and } 949 \text { men with } \\
\text { DM were followed up with to } \\
\text { determine the duration and } \\
\text { frequency of their work } \\
\text { disability. The mean } \\
\text { follow-up periods were } 3.2 \\
\text { years in the GAZEL Study, } \\
\text { 4.6 years in the Whitehall II } \\
\text { Study, and } 4.7 \text { years in the } \\
\text { Public Sector Study. }\end{array}$ & $\begin{array}{l}\text { Psychological distress was associated with increased duration and } \\
\text { frequency of work disability among employees with DM. Job strain } \\
\text { was associated with increased absence frequency but not with } \\
\text { absence duration. }\end{array}$ \\
\hline $\begin{array}{l}\text { (13) Kasper Olesen, Bryan } \\
\text { Cleal and Ingrid Willaing, } \\
\text { published in } 2020 \text { [23] }\end{array}$ & $\begin{array}{l}\text { Steno Diabetes } \\
\text { Center, } \\
\text { Copenhagen, } \\
\text { Denmark }\end{array}$ & $\begin{array}{l}\text { Single self-reported } \\
\text { items were used to } \\
\text { obtain information } \\
\text { about DM via a } \\
\text { status survey. }\end{array}$ & $\begin{array}{l}\text { Employees } \\
\text { working with } \\
\text { T2DM }\end{array}$ & $\begin{array}{l}\text { This study was based on } \\
\text { survey data from } 2415 \\
\text { working Danes with T2DM ( } n \\
=586 \text { ) and without T2DM ( } \\
\text { = 1829) recruited from online } \\
\text { panels. Single self-reported } \\
\text { items were used to obtain } \\
\text { information about DM status, } \\
\text { exposure to discrimination, } \\
\text { and other individual factors. }\end{array}$ & $\begin{array}{l}\text { People with T2DM reported a relatively poor psychosocial working } \\
\text { environment compared with the general working population, but the } \\
\text { difference was removed by adjusting for overweight/obesity. This } \\
\text { indicates T2DM alone is not a source of stigma and discrimination in } \\
\text { the work context. Levels of perceived discrimination were notably } \\
\text { lower than expected among people with DM as a whole, but many } \\
\text { people still continue to be exposed to the destructive effects of } \\
\text { discrimination in the work context. }\end{array}$ \\
\hline
\end{tabular}


Table A1. Cont..

\begin{tabular}{|c|c|c|c|c|c|}
\hline $\begin{array}{l}\text { Author(s)/ } \\
\text { Year of Publication }\end{array}$ & $\begin{array}{l}\text { Research } \\
\text { Setting(s) }\end{array}$ & Tool(s) Used & Study Group(s) & Methodology & Result(s) \\
\hline $\begin{array}{l}\text { (14) Mette Andersen Nexø, } \\
\text { John Pedersen, Bryan Cleal } \\
\text { and Jakob B. Bjorner, } \\
\text { published in } 2020 \text { [37] }\end{array}$ & $\begin{array}{l}\text { Danish } \\
\text { National } \\
\text { Patient } \\
\text { Register, } \\
\text { Denmark }\end{array}$ & $\begin{array}{l}\text { Multi-state Cox } \\
\text { proportional hazards } \\
\text { analyses }\end{array}$ & $\begin{array}{l}\text { Employees } \\
\text { working } \\
\text { with DM }\end{array}$ & $\begin{array}{l}\text { This was a retrospective } \\
\text { cohort study. Individuals } \\
\text { with T1DM }(n=431) \text { and } \\
\text { T2DM ( } n=4047) \text { were } \\
\text { identified in Danish national } \\
\text { registers from } 1994 \text { to } 2011 \\
\text { and compared with } \\
\text { individuals without DM ( } n= \\
\text { 101,295). Multistate Cox } \\
\text { proportional hazards analysis } \\
\text { estimated hazard ratios (HR) } \\
\text { with 95\% confidence intervals } \\
\text { (CI) for transitions among } \\
\text { work, sickness absence, } \\
\text { unemployment, and } \\
\text { disability pension. }\end{array}$ & $\begin{array}{l}\text { Both T1DM and T2DM affect labor market outcomes, but future } \\
\text { studies also should consider comorbidity and social gradient. }\end{array}$ \\
\hline $\begin{array}{l}\text { (15) Maryam Binesh, } \\
\text { Rokhsareh Aghili, and } \\
\text { Afsoon Hassani Mehraban, } \\
\text { published in } 2021 \text { [31] }\end{array}$ & $\begin{array}{c}\text { Institute of } \\
\text { Endocrinology } \\
\text { and } \\
\text { Metabolism, } \\
\text { affiliated with } \\
\text { Iran } \\
\text { University of } \\
\text { Medical } \\
\text { Sciences, Iran }\end{array}$ & $\begin{array}{l}\text { Diabetes Distress } \\
\text { Scale and } \\
\text { Life Balance Inventory }\end{array}$ & $\begin{array}{c}\text { A total of } 160 \\
\text { individuals ( } 80 \\
\text { people with DM } \\
\text { and } 80 \\
\text { without DM) }\end{array}$ & $\begin{array}{l}\text { A comparative cross-sectional } \\
\text { study was conducted using } \\
\text { simple nonprobability } \\
\text { sampling. The Life Balance } \\
\text { Inventory evaluated } \\
\text { participants' occupational } \\
\text { balance. Blood samples were } \\
\text { taken from those with DM } \\
\text { and analyzed. Psychological } \\
\text { distress was also evaluated in } \\
\text { people with DM using the } \\
\text { Diabetes Distress Scale. }\end{array}$ & $\begin{array}{l}\text { Distress was the only biopsychological factor associated with } \\
\text { occupational balance in people with DM. A higher level of distress is } \\
\text { associated with lower occupational balance and poor glycemic control } \\
\text { in this population. }\end{array}$ \\
\hline
\end{tabular}


Table A1. Cont..

\begin{tabular}{|c|c|c|c|c|c|}
\hline $\begin{array}{c}\text { Author(s)/ } \\
\text { Year of Publication }\end{array}$ & $\begin{array}{l}\text { Research } \\
\text { Setting(s) }\end{array}$ & Tool(s) Used & Study Group(s) & Methodology & Result(s) \\
\hline $\begin{array}{c}\text { (16) Tomomi Nakao, } \\
\text { Chizuko Takeishi, Chiyo } \\
\text { Tsutsumi, Yuichi Sato, Yuji } \\
\text { Uchizono, and Yasuko } \\
\text { Shimizu, published in } \\
2020 \text { [22] }\end{array}$ & $\begin{array}{l}\text { Outpatient } \\
\text { clinics at three } \\
\text { general } \\
\text { hospitals and } \\
\text { three clinics in } \\
\text { Japan }\end{array}$ & $\begin{array}{l}\text { The Daily Time } \\
\text { Management Scale for } \\
\text { Use by Working } \\
\text { People with Type } 2 \\
\text { Diabetes }\end{array}$ & $\begin{array}{l}\text { A total of } 277 \\
\text { working people } \\
\text { with T2DM }\end{array}$ & $\begin{array}{l}\text { A descriptive cross-sectional } \\
\text { study using a questionnaire } \\
\text { survey was administered to } \\
277 \text { working people with } \\
\text { T2DM. It included a daily } \\
\text { time management scale and } \\
\text { questions about age, gender, } \\
\text { hemoglobin A1c levels, shift } \\
\text { work, managerial position, } \\
\text { and average working hours. } \\
\text { Multiple regression analysis } \\
\text { was used to assess the } \\
\text { relationship between daily } \\
\text { time management and each } \\
\text { factor, adjusted for age, } \\
\text { gender, and hemoglobin A1c. }\end{array}$ & $\begin{array}{l}\text { When providing time management support to working people with } \\
\text { T2DM, any assessment should consider the availability of shift work, } \\
\text { whether employees are in a managerial position, and their work hours }\end{array}$ \\
\hline $\begin{array}{l}\text { (17) Margaret McCarthy, } \\
\text { Allison Vorderstrasse, } \\
\text { Joeyee Yan, Angie Portillo, } \\
\text { and Victoria Vaughan } \\
\text { Dickson, published in } \\
2021 \text { [40] }\end{array}$ & $\begin{array}{l}\text { Local } \\
\text { academic } \\
\text { medical center } \\
\text { and Research } \\
\text { Match, US }\end{array}$ & $\begin{array}{l}\text { Work Ability Index } \\
\text { and Karasek's Job } \\
\text { Content } \\
\text { Questionnaire (JCQ) }\end{array}$ & $\begin{array}{l}\text { A total of } 101 \\
\text { employees } \\
\text { with DM }\end{array}$ & $\begin{array}{l}\text { This study used a convergent } \\
\text { mixed-method design. We } \\
\text { assessed the relationship } \\
\text { between work-related factors } \\
\text { and work ability using } \\
\text { bivariate statistics and } \\
\text { logistic regression. Work } \\
\text { ability was measured using } \\
\text { the Work Ability Index, and } \\
\text { Karasek's JCQ was employed } \\
\text { to measure job demands. } \\
\text { Qualitative interviews } \\
\text { explored the relationship } \\
\text { between DM and work. }\end{array}$ & $\begin{array}{l}\text { Social support and work-life balance are associated with excellent } \\
\text { work ability. Therefore, engaging workers with DM in workplace } \\
\text { educational programs may take strategic efforts by occupational } \\
\text { health staff. }\end{array}$ \\
\hline
\end{tabular}


Table A1. Cont..

\begin{tabular}{|c|c|c|c|c|c|}
\hline $\begin{array}{c}\text { Author(s)/ } \\
\text { Year of Publication }\end{array}$ & $\begin{array}{l}\text { Research } \\
\text { Setting(s) }\end{array}$ & Tool(s) Used & Study Group(s) & Methodology & Result(s) \\
\hline $\begin{array}{l}\text { (18) Helena B. Nielsen, } \\
\text { Louise L. Ovesen, Laust H. } \\
\text { Mortensen, Cathrine J. Lau, } \\
\text { and Lene E. Joensen, } \\
\text { published in } 2016 \text { [29] }\end{array}$ & $\begin{array}{c}\text { Steno Diabetes } \\
\text { Center, Capital } \\
\text { Region in } \\
\text { Denmark }\end{array}$ & $\begin{array}{c}\text { Danish National } \\
\text { Health Survey ("How } \\
\text { Are You?") }\end{array}$ & $\begin{array}{l}\text { Employees with } \\
\text { T1DM were } \\
\text { compared to } \\
\text { employees } \\
\text { without DM. }\end{array}$ & $\begin{array}{l}\text { A total of 2,415 adults (aged } \\
\text { 18-98 years) with T1DM were } \\
\text { compared to } 48,511 \text { adults } \\
\text { (aged 18-103 years) from the } \\
\text { general population. Data } \\
\text { were obtained from two } \\
\text { cross-sectional surveys } \\
\text { conducted in } 2010 \text { and } 2011 \\
\text { of adults living or treated in } \\
\text { the Capital Region in } \\
\text { Denmark. Differences } \\
\text { between adults with T1DM } \\
\text { and the general population } \\
\text { were standardized for age } \\
\text { and sex and analyzed using } \\
\text { linear probability models and } \\
\text { negative binomial regression. }\end{array}$ & $\begin{array}{c}\text { Compared to the general population, adults with T1DM experienced } \\
\text { lower health-related QoL (HRQoL), were more frequently } \\
\text { unemployed, had more sick leave per year, and were slightly better } \\
\text { educated. Differences in HRQoL and employment increased with age } \\
\text { and were greater among women than men. No significant differences } \\
\text { were found with regard to working hours. }\end{array}$ \\
\hline
\end{tabular}


Table A1. Cont.

\begin{tabular}{|c|c|c|c|c|c|}
\hline $\begin{array}{c}\text { Author(s)/ } \\
\text { Year of Publication }\end{array}$ & $\begin{array}{l}\text { Research } \\
\text { Setting(s) }\end{array}$ & Tool(s) Used & Study Group(s) & Methodology & Result(s) \\
\hline $\begin{array}{l}\text { (20) Anne B. Hansen, Leslie } \\
\text { Stayner, Johnni Hansen, } \\
\text { and Zorana J Andersen, } \\
\text { published in } 2016 \text { [20] }\end{array}$ & $\begin{array}{c}\text { Danish } \\
\text { Diabetes } \\
\text { Register for } \\
\text { incidence of } \\
\text { DM, Denmark }\end{array}$ & $\begin{array}{l}\text { Cox proportional } \\
\text { hazards model }\end{array}$ & Nurses & $\begin{array}{l}\text { We used the Danish nurse } \\
\text { cohort, with } 28,731 \\
\text { participating female nurses } \\
\text { recruited in 1993 (19,898) or } \\
1999 \text { (8833), when } \\
\text { self-reported baseline } \\
\text { information on DM } \\
\text { prevalence, lifestyle, and } \\
\text { working time were collected. } \\
\text { We followed them in the } \\
\text { Danish Diabetes Register for } \\
\text { incidence of DM until 2013. } \\
\text { Nurses reported whether } \\
\text { they worked night, evening, } \\
\text { rotating, or day shifts. We } \\
\text { analyzed the association } \\
\text { between working time and } \\
\text { DM incidence using the Cox } \\
\text { proportional hazards model } \\
\text { adjusted for DM risk factors, } \\
\text { separately with and without } \\
\text { adjustment for BMI, which } \\
\text { might be an intermediate } \\
\text { variable. }\end{array}$ & $\begin{array}{l}\text { Danish nurses working night and evening shifts have an increased risk } \\
\text { for DM, with the highest risk associated with current night-shift work. }\end{array}$ \\
\hline
\end{tabular}

(21) Robert M. Gerbo, Chuan Fang Jin, and Karen

Clark, published in 2019 [34]
Department of

Occupational

and Environmental

Sciences, USA
Blanket employment policies that disqualify workers with DM are unnecessary in many occupational fields. In assessing occupationa risks and fitness for duty in workers with DM, it is important to perform an individualized assessment of the worker and consider the risk factors for hypoglycemia, information from the treating clinician, essential job functions, and availability of reasonable accommodations (if needed). 
Table A1. Cont.

\begin{tabular}{|c|c|c|c|c|c|}
\hline $\begin{array}{c}\text { Author(s)/ } \\
\text { Year of Publication }\end{array}$ & $\begin{array}{l}\text { Research } \\
\text { Setting(s) }\end{array}$ & Tool(s) Used & Study Group(s) & Methodology & Result(s) \\
\hline $\begin{array}{l}\text { (22) Jenni Ervasti, Marianna } \\
\text { Virtanen, Jaana Pentti, Tea } \\
\text { Lallukka, Petter Tinghög, } \\
\text { Linnea Kjeldgard, Ellenor } \\
\text { Mittendorfer-Rutz, and } \\
\text { Kristina Alexanderson, } \\
\text { published in } 2015 \text { [38] }\end{array}$ & $\begin{array}{l}\text { Nationwide } \\
\text { Swedish } \\
\text { registers and } \\
\text { linked, } \\
\text { Sweden }\end{array}$ & Cohort study & $\begin{array}{l}\text { Individuals with } \\
\text { incident DM } \\
\text { and individuals } \\
\text { without DM }\end{array}$ & $\begin{array}{c}\text { This Swedish } \\
\text { population-based cohort } \\
\text { study with registered data } \\
\text { included } 14,428 \text { individuals } \\
\text { with incident DM in } 2006 \text { and } \\
39,702 \text { individuals without } \\
\text { DM from } 2003 \text { to } 2009 \text {. }\end{array}$ & $\begin{array}{c}\text { Work disability was substantially higher among people with DM } \\
\text { (overall mean = } 95 \text { days per year over } 7 \text { years, SD = 143) than among } \\
\text { those without DM (mean = } 35 \text { days, } \mathrm{SD}=95 \text { ). The risk of work } \\
\text { disability was slightly higher after DM diagnosis than before and } \\
\text { compared with the risk of those without DM. The trajectory of work } \\
\text { disability was already increasing before diagnosis, increased more at } \\
\text { the time of diagnosis, and plateaued after diagnosis. Individual } \\
\text { sociodemographic characteristics and comorbidities were taken } \\
\text { into account }\end{array}$ \\
\hline $\begin{array}{l}\text { (23) Kimberly J. Smit, Sonya } \\
\text { S. Deschênes, and Norbert } \\
\text { Schmitz, published in } \\
2018 \text { [35] }\end{array}$ & $\begin{array}{l}\text { Diabetes } \\
\text { Center, UK }\end{array}$ & Systematic review & $\begin{array}{l}\text { All studies } \\
\text { about diabtets }\end{array}$ & $\begin{array}{l}\text { We searched seven databases } \\
\text { for studies examining the } \\
\text { longitudinal relationship } \\
\text { between anxiety and DM. } \\
\text { Two independent reviewers } \\
\text { screened studies from a } \\
\text { population aged } 16 \text { or older } \\
\text { that examined either anxiety } \\
\text { as a risk factor for incident } \\
\text { DM or DM as a risk factor for } \\
\text { incident anxiety. In addition, } \\
\text { studies that met eligibility } \\
\text { criteria were put forward for } \\
\text { data extraction and } \\
\text { meta-analysis. }\end{array}$ & $\begin{array}{l}\text { There was an association between baseline anxiety and incident DM. } \\
\text { The results also indicated the need for more research to examine the } \\
\text { direction of association from DM to incident anxiety. This work adds } \\
\text { to the growing body of evidence that poor mental health increases the } \\
\text { risk of developing DM. }\end{array}$ \\
\hline $\begin{array}{l}\text { (24) Nao Sonoda, Soichiro } \\
\text { Watanabe, Yuko Ohno, } \\
\text { Kayo Godai, Chieko } \\
\text { Hatamochi, Yoshie } \\
\text { Sugimoto, Satoko Okawa, } \\
\text { Maiko Shikama, and Akiko } \\
\text { Morimoto, published } \\
\text { in 2019 [28] }\end{array}$ & $\begin{array}{l}\text { Institutional } \\
\text { Review Board } \\
\text { of Osaka } \\
\text { University, } \\
\text { Japan }\end{array}$ & $\begin{array}{l}\text { Self-administered } \\
\text { questionnaire and } \\
\text { specific health } \\
\text { checkup data }\end{array}$ & $\begin{array}{c}\text { Employees with } \\
\text { DM }\end{array}$ & $\begin{array}{l}\text { This cross-sectional study } \\
\text { was conducted in } 2018 . \\
\text { Participants were } 140 \\
\text { full-time employees with } \\
\text { T2DM aged over } 40 \text { years. } \\
\text { Participants were classified } \\
\text { into two groups: a dropout } \\
\text { group and a continuation } \\
\text { group. Work-related, } \\
\text { personal, and DM-related } \\
\text { factors were evaluated using } \\
\text { a self-administered } \\
\text { questionnaire and specific } \\
\text { health checkup data. }\end{array}$ & $\begin{array}{l}\text { Our findings suggest supervisor support, age, and metabolic } \\
\text { syndrome are important factors related to dropout from outpatient } \\
\text { DM treatment visits among Japanese male employees with DM. }\end{array}$ \\
\hline
\end{tabular}


Table A1. Cont..

\begin{tabular}{|c|c|c|c|c|c|}
\hline $\begin{array}{c}\text { Author(s)/ } \\
\text { Year of Publication }\end{array}$ & $\begin{array}{l}\text { Research } \\
\text { Setting(s) }\end{array}$ & Tool(s) Used & Study Group(s) & Methodology & Result(s) \\
\hline $\begin{array}{l}\text { (25) Isabela Fernandes de } \\
\text { Aguiar Tonetto, Marcelo } \\
\text { Henrique Barbosa Baptista, } \\
\text { Danielle dos Santos } \\
\text { Gomides and Ana Emilia } \\
\text { Pace, published in } 2019 \text { [30] }\end{array}$ & $\begin{array}{l}\text { Study carried } \\
\text { out in primary, } \\
\text { secondary, and } \\
\text { tertiary health } \\
\text { care units with } \\
\text { individuals in } \\
\text { outpatient } \\
\text { care, Brazil }\end{array}$ & $\begin{array}{l}\text { The validated } \\
\text { Diabetes-39 } \\
\text { instrument }\end{array}$ & $\begin{array}{l}\text { A total of } 53 \\
\text { people with } \\
\text { T2DM }\end{array}$ & $\begin{array}{l}\text { This was a quantitative, } \\
\text { cross-sectional, and } \\
\text { descriptive study. The sample } \\
\text { consisted of } 53 \text { people } \\
\text { with T2DM. }\end{array}$ & $\begin{array}{l}\text { QoL tends to worsen as the disease worsens. The results suggest QoL } \\
\text { is related to sociodemographic and clinical variables. Therefore, these } \\
\text { should be considered in the provision of care. }\end{array}$ \\
\hline $\begin{array}{l}\text { (26) Rose Nabi Deborah } \\
\text { Karimi Muthuri, Flavia } \\
\text { Senkubuge, and Charles } \\
\text { Hongoro, published in } \\
2020 \text { [16] }\end{array}$ & $\begin{array}{l}\text { Public and } \\
\text { mission } \\
\text { hospitals in } \\
\text { the Meru } \\
\text { County of } \\
\text { Kenya }\end{array}$ & $\begin{array}{l}\text { The EuroQol } \\
\text { five-dimension } \\
\text { five-level instrument } \\
\text { (EQ-5D-5L) }\end{array}$ & $\begin{array}{c}\text { A total of } 32 \\
\text { HCWs }\end{array}$ & $\begin{array}{l}\text { A cross-sectional study } \\
\text { design was undertaken } \\
\text { among } 553 \text { HCWs across } 24 \\
\text { hospitals in Meru County. }\end{array}$ & $\begin{array}{c}\text { Personal, job-related attributes and work environment characteristics } \\
\text { are significant predictors of HCWs' HRQoL. Thus, health } \\
\text { policymakers and managers must consider these factors when } \\
\text { developing and implementing policies and programs aimed at } \\
\text { promoting HRQoL among HCWs. }\end{array}$ \\
\hline $\begin{array}{l}\text { (27) Evangelia Nena, Maria } \\
\text { Katsaouni, Paschalis } \\
\text { Steiropoulos, Evangelos } \\
\text { Theodorou, Theodoros C } \\
\text { Constantinidis, and } \\
\text { Grigorios Tripsianis, } \\
\text { published in } 2018 \text { [15] }\end{array}$ & $\begin{array}{l}\text { Tertiary } \\
\text { university } \\
\text { hospital in } \\
\text { Greece }\end{array}$ & $\begin{array}{l}\text { WHO-5 Well-Being } \\
\text { Index (WHO-5), a } \\
\text { questionnaire on } \\
\text { demographics and } \\
\text { medical history, and } \\
\text { the Shift Work } \\
\text { Disorders Screening } \\
\text { Questionnaire } \\
\text { (SWDSQ) }\end{array}$ & HCWs & $\begin{array}{l}\text { This was a cross-sectional } \\
\text { study of HCWs: } 312 \\
\text { employees working either in } \\
\text { an irregular shift system or } \\
\text { exclusively in morning shifts. } \\
\text { All participants answered } \\
\text { thequestionnair Shift workers } \\
\text { completed the SWDSQ. }\end{array}$ & $\begin{array}{l}\text { Most shift workers (58.2\%) were somehow or totally dissatisfied with } \\
\text { their sleep quality. Regression analysis revealed the following } \\
\text { independent determinants for sleep impairment: parenthood, age } \\
36-45 \text { years, night shifts / week, and working more than } 5 \text { years in an } \\
\text { irregular shift system. In addition, DM was the most common medical } \\
\text { condition reported by shift workers. Comparison between the two } \\
\text { groups revealed significant impairment in the WHO-5 total score and } \\
4 \text { of } 5 \text { items. Thus, shift work impairs QoL, whereas employees' } \\
\text { duration, frequency, age, and family status can adversely affect sleep. }\end{array}$ \\
\hline
\end{tabular}


Table A2. Quality Assessment of Included Studies.

\begin{tabular}{|c|c|c|c|c|c|c|c|c|c|c|}
\hline $\begin{array}{l}\text { Authors' } \\
\text { Name(s) }\end{array}$ & $\begin{array}{l}\text { Title and } \\
\text { Abstract }\end{array}$ & $\begin{array}{c}\text { Introduction } \\
\text { and Aim }\end{array}$ & $\begin{array}{c}\text { Methodology and } \\
\text { Sampling Data }\end{array}$ & $\begin{array}{c}\text { Analyzing the } \\
\text { Data }\end{array}$ & $\begin{array}{l}\text { Bias and } \\
\text { Ethics }\end{array}$ & Results & $\begin{array}{l}\text { Transferability/ } \\
\text { Generalizability }\end{array}$ & Implications & Usefulness & $\begin{array}{c}\text { Total Score } \\
\quad / 36 \\
\end{array}$ \\
\hline $\begin{array}{c}\text { Coetzee et al., } \\
2019 \text { [17] }\end{array}$ & 4 & 4 & 3 & 3 & 3 & 4 & 3 & 3 & 3 & 30 \\
\hline $\begin{array}{l}\text { Hegde et al., } \\
2015 \text { [18] }\end{array}$ & 4 & 4 & 4 & 4 & 3 & 4 & 2 & 3 & 3 & 31 \\
\hline $\begin{array}{l}\text { Huang et al., } \\
2016 \text { [19] }\end{array}$ & 4 & 4 & 4 & 4 & 3 & 4 & 3 & 3 & 3 & 32 \\
\hline $\begin{array}{l}\text { Manodpitipong } \\
\text { et al., 2017 [21] }\end{array}$ & 3 & 4 & 4 & 4 & 3 & 4 & 3 & 3 & 3 & 31 \\
\hline $\begin{array}{c}\text { Nakao et al., } \\
2021 \text { [22] }\end{array}$ & 4 & 4 & 4 & 4 & 3 & 4 & 3 & 3 & 3 & 32 \\
\hline $\begin{array}{l}\text { Seuring et al., } \\
2015 \text { [24] }\end{array}$ & 4 & 4 & 3 & 4 & 2 & 4 & 2 & 2 & 3 & 32 \\
\hline $\begin{array}{l}\text { Olesen et al., } \\
2020 \text { [23] }\end{array}$ & 4 & 4 & 2 & 2 & 1 & 3 & 2 & 3 & 2 & 24 \\
\hline $\begin{array}{l}\text { Hakkarainen } \\
\text { et al., } 2016 \text { [26] }\end{array}$ & 4 & 4 & 4 & 4 & 3 & 3 & 2 & 4 & 3 & 34 \\
\hline $\begin{array}{c}\text { Loerbroks } \\
\text { et al., } 2018 \text { [27] }\end{array}$ & 4 & 4 & 4 & 4 & 3 & 4 & 3 & 4 & 4 & 34 \\
\hline $\begin{array}{l}\text { Binesh et al., } \\
2021 \text { [31] }\end{array}$ & 4 & 4 & 4 & 4 & 3 & 4 & 2 & 3 & 3 & 31 \\
\hline $\begin{array}{l}\text { Abu et al., } \\
2016 \text { [32] }\end{array}$ & 4 & 4 & 4 & 4 & 4 & 4 & 2 & 3 & 3 & 32 \\
\hline $\begin{array}{c}\text { Galarraga \& } \\
\text { Llahana, } \\
2018 \text { [33] }\end{array}$ & 4 & 4 & 4 & 4 & 3 & 4 & 2 & 4 & 4 & 33 \\
\hline $\begin{array}{l}\text { Pasmooij et al., } \\
2016 \text { [25] }\end{array}$ & 4 & 3 & 4 & 4 & 4 & 4 & 4 & 3 & 3 & 33 \\
\hline
\end{tabular}


Table A2. Cont.

\begin{tabular}{|c|c|c|c|c|c|c|c|c|c|c|}
\hline $\begin{array}{l}\text { Authors' } \\
\text { Name(s) }\end{array}$ & $\begin{array}{l}\text { Title and } \\
\text { Abstract }\end{array}$ & $\begin{array}{l}\text { Introduction } \\
\text { and Aim }\end{array}$ & $\begin{array}{l}\text { Methodology and } \\
\text { Sampling Data }\end{array}$ & $\begin{array}{c}\text { Analyzing the } \\
\text { Data }\end{array}$ & $\begin{array}{l}\text { Bias and } \\
\text { Ethics }\end{array}$ & Results & $\begin{array}{c}\text { Transferability/ } \\
\text { Generalizability }\end{array}$ & Implications & Usefulness & $\begin{array}{c}\text { Total Score } \\
\quad / 36\end{array}$ \\
\hline $\begin{array}{l}\text { Smith et al., } \\
2018 \text { [35] }\end{array}$ & 4 & 4 & 4 & 4 & 3 & 4 & 2 & 2 & 3 & 30 \\
\hline $\begin{array}{l}\text { Nexø et al., } \\
2020 \text { [37] }\end{array}$ & 4 & 4 & 3 & 4 & 3 & 4 & 2 & 3 & 3 & 34 \\
\hline $\begin{array}{c}\text { Gerbo et al., } \\
2019 \text { [34] }\end{array}$ & 4 & 4 & 3 & 4 & 2 & 4 & 2 & 3 & 3 & 29 \\
\hline $\begin{array}{c}\text { McCarthy } \\
\text { et al., } 2021 \text { [40] }\end{array}$ & 4 & 4 & 4 & 4 & 4 & 3 & 4 & 4 & 4 & 35 \\
\hline $\begin{array}{l}\text { Ervasti et al., } \\
2015 \text { [38] }\end{array}$ & 4 & 4 & 4 & 4 & 3 & 4 & 3 & 3 & 3 & 32 \\
\hline $\begin{array}{l}\text { Nielsen et al., } \\
2016 \text { [29] }\end{array}$ & 4 & 4 & 4 & 4 & 2 & 4 & 3 & 3 & 4 & 32 \\
\hline $\begin{array}{c}\text { Ervasti et al., } \\
2016 \text { [39] }\end{array}$ & 4 & 4 & 4 & 3 & 3 & 4 & 4 & 3 & 3 & 32 \\
\hline $\begin{array}{l}\text { Tonetto et al., } \\
2019 \text { [30] }\end{array}$ & 4 & 4 & 4 & 4 & 3 & 3 & 4 & 3 & 3 & 32 \\
\hline $\begin{array}{l}\text { Nena et al., } \\
2018 \text { [15] }\end{array}$ & 4 & 4 & 4 & 4 & 4 & 3 & 3 & 3 & 3 & 32 \\
\hline $\begin{array}{l}\text { Muthuri et al., } \\
2021 \text { [16] }\end{array}$ & 4 & 4 & 4 & 4 & 4 & 3 & 4 & 3 & 4 & 34 \\
\hline
\end{tabular}




\section{References}

1. Saedi, E.; Gheini, M.R.; Faiz, F.; Arami, M.A. Diabetes mellitus and cognitive impairments. World J. Diabetes 2016, 7, 412-422. [CrossRef]

2. World Health Organization. Classification of Diabetes Mellitus. Available online: https://apps.who.int/iris/handle/10665/3251 82 (accessed on 28 January 2019).

3. Alqahtani, M.; Almutairi, F.E.; Albasseet, A.O.; Almutairi, K.E. Knowledge, Attitude, and Practice of Diabetes Mellitus among the Saudi Population in Riyadh, Saudi Arabia: A Quantitative Study. Cureus 2020, 12, e6601. [CrossRef]

4. Karimi, M.; Brazier, J. Health, Health-Related Quality of Life, and Quality of Life: What is the Difference? PharmacoEconomics 2016, 34, 645-649. [CrossRef] [PubMed]

5. Memari, K. A Comparison of Generic and Disease-Specific Health-Related Quality of Life Measures in Hemophilia Patients: An Online Study. 2019. Available online: https:/ / conservancy.umn.edu/handle/11299/206216 (accessed on 5 September 2021).

6. Hansen, U.M.; Cleal, B.; Willaing, I.; Tjørnhøj-Thomsen, T. Managing type 1 diabetes in the context of work life: A matter of containment. Soc. Sci. Med. 2018, 219, 70-77. [CrossRef] [PubMed]

7. Pequeno, N.P.F.; Cabral, N.L.D.A.; Marchioni, D.M.; Lima, S.C.V.C.; Lyra, C.D.O. Quality of life assessment instruments for adults: A systematic review of population-based studies. Health Qual. Life Outcomes 2020, 18, 1-13. [CrossRef]

8. Trikkalinou, A.; Papazafiropoulou, A.K.; Melidonis, A. Type 2 diabetes and quality of life. World J. Diabetes 2017, 8, 120-129. [CrossRef] [PubMed]

9. Almasri, D.M.; Noor, A.O.; Ghoneim, R.H.; Bagalagel, A.A.; Almetwazi, M.; Baghlaf, N.A.; Hamdi, E.A. The impact of diabetes mellitus on health-related quality of life in Saudi Arabia. Saudi Pharm. J. 2020, 28, 1514-1519. [CrossRef] [PubMed]

10. Gebremedhin, T.; Workicho, A.; Angaw, D.A. Health-related quality of life and its associated factors among adult patients with type II diabetes attending Mizan Tepi University Teaching Hospital, Southwest Ethiopia. BMJ Open Diabetes Res. Care 2019, 7, e000577. [CrossRef] [PubMed]

11. Munn, Z.; Peters, M.D.J.; Stern, C.; Tufanaru, C.; McArthur, A.; Aromataris, E. Systematic review or scoping review? Guidance for authors when choosing between a systematic or scoping review approach. BMC Med. Res. Methodol. 2018, 18, 1-7. [CrossRef] [PubMed]

12. Moher, D.; Liberati, A.; Tetzlaff, J.; Altman, D.G. Preferred Reporting Items for Systematic Reviews and Meta-Analyses: The PRISMA Statement. PLoS Med. 2009, 6, e1000097. [CrossRef] [PubMed]

13. Hawker, S.; Payne, S.; Kerr, C.; Hardey, M.; Powell, J. Appraising the evidence: Reviewing disparate data systematically. Qualitative Health Research. Qual. Health Res. 2002, 12, 1284-1299. [CrossRef] [PubMed]

14. Hudson, B.F.; Flemming, K.; Shulman, C.; Candy, B. Challenges to access and provision of palliative care for people who are homeless: A systematic review of qualitative research. BMC Palliat. Care 2016, 15, 1-18. [CrossRef] [PubMed]

15. Nena, E.; Katsaouni, M.; Steiropoulos, P.; Theodorou, E.; Constantinidis, T.C.; Tripsianis, G. Effect of shift work on sleep, health, and quality of life of health-care workers. Indian J. Occup. Environ. Med. 2018, 22, 29-34. [CrossRef] [PubMed]

16. Muthuri, R.; Senkubuge, F.; Hongoro, C. Predictors of Health-Related Quality of Life among Healthcare Workers in the Context of Health System Strengthening in Kenya. Healthcare 2020, 9, 18. [CrossRef]

17. Coetzee, A.; Beukes, A.; Dreyer, R.; Solomon, S.; Van Wyk, L.; Mistry, R.; Conradie, M.; Van De Vyver, M. The prevalence and risk factors for diabetes mellitus in healthcare workers at Tygerberg hospital, Cape Town, South Africa: A retrospective study. J. Endocrinol. Metab. Diabetes S. Afr. 2019, 24, 77-82. [CrossRef]

18. Hegde, S.; Sathiyanarayanan, S.; Venkateshwaran, S.; Sasankh, A.; Ganeshkumar, P.; Balaji, R. Prevalence of Diabetes, Hypertension and Obesity among Doctors and Nurses in a Medical College Hospital in Tamil Nadu, India. Natl. J. Res. Community Med. 2015, 4, 235-239.

19. Huang, H.-L.; Pan, C.-C.; Wang, S.-M.; Kung, P.-T.; Chou, W.-Y.; Tsai, W.-C. The incidence risk of type 2 diabetes mellitus in female nurses: A nationwide matched cohort study. BMC Public Health 2016, 16, 443. [CrossRef] [PubMed]

20. Hansen, A.B.; Stayner, L.; Hansen, J.; Andersen, Z.J. Night shift work and incidence of diabetes in the Danish Nurse Cohort. Occup. Environ. Med. 2016, 73, 262-268. [CrossRef]

21. Manodpitipong, A.; Saetung, S.; Nimitphong, H.; Siwasaranond, N.; Wongphan, T.; Sornsiriwong, C.; Luckanajantachote, P.; Mangit, P.; Keesukphan, P.; Crowley, S.; et al. Night-shift work is associated with poorer glycaemic control in patients with type 2 diabetes. J. Sleep Res. 2017, 26, 764-772. [CrossRef]

22. Nakao, T.; Takeishi, C.; Tsutsumi, C.; Sato, Y.; Uchizono, Y.; Shimizu, Y. Employment factors associated with daily time management in working people with type 2 diabetes. Jpn. J. Nurs. Sci. 2021, 18, e12395. [CrossRef] [PubMed]

23. Olesen, K.; Cleal, B.; Willaing, I. Discrimination and stigma among people with type 2 diabetes in the workplace: Prejudice against illness or obesity? Public Health 2020, 180, 100-101. [CrossRef] [PubMed]

24. Seuring, T.; Goryakin, Y.; Suhrcke, M. The impact of diabetes on employment in Mexico. Econ. Hum. Biol. 2015, 18, 85-100. [CrossRef]

25. Kouwenhoven-Pasmooij, T.; Burdorf, A.; Roos-Hesselink, J.; Hunink, M.; Robroek, S. Cardiovascular disease, diabetes and early exit from paid employment in Europe; the impact of work-related factors. Int. J. Cardiol. 2016, 215, 332-337. [CrossRef] [PubMed] 
26. Hakkarainen, P.; Moilanen, L.; Hänninen, V.; Heikkinen, J.; Räsänen, K. Work-related diabetes distress among Finnish workers with type 1 diabetes: A national cross-sectional survey. J. Occup. Med. Toxicol. 2016, 11, 11. [CrossRef] [PubMed]

27. Loerbroks, A.; Nguyen, X.Q.; Vu-Eickmann, P.; Krichbaum, M.; Kulzer, B.; Icks, A.; Angerer, P. Psychosocial working conditions and diabetes self-management at work: A qualitative study. Diabetes Res. Clin. Pract. 2018, 140, 129-138. [CrossRef] [PubMed]

28. Sonoda, N.; Watanabe, S.; Ohno, Y.; Godai, K.; Hatamochi, C.; Sugimoto, Y.; Okawa, S.; Shikama, M.; Morimoto, A. Work-related, personal, and diabetes-related factors relevant to dropout from outpatient diabetes treatment visits among Japanese male employees with diabetes. Diabetol. Int. 2019, 11, 261-268. [CrossRef] [PubMed]

29. Nielsen, H.B.; Ovesen, L.L.; Mortensen, L.H.; Lau, C.J.; Joensen, L.E. Type 1 diabetes, quality of life, occupational status and education level-A comparative population-based study. Diabetes Res. Clin. Pract. 2016, 121, 62-68. [CrossRef]

30. Tonetto, I.F.D.A.; Baptista, M.H.B.; Gomides, D.D.S.; Pace, A.E. Quality of life of people with diabetes mellitus. Rev. Esc. Enferm. USP 2019, 53, e03424. [CrossRef] [PubMed]

31. Binesh, M.; Aghili, R.; Mehraban, A.H. Occupational balance in people with type-2 diabetes: A comparative cross-sectional study. Br. J. Occup. Ther. 2021, 84, 122-129. [CrossRef]

32. Abu, M.E.; Hegazy, N.N.; Mohamed, S.G. The effect of diabetes and hypertension on work productivity and job satisfaction. Menoufia Med. J. 2016, 29, 1106-1111. [CrossRef]

33. Galarraga, M.M.; Llahana, S. Diabetes: A Literature Review. 2018. Available online: https://diabetesonthenet.com/Journaldiabetes-nursing/quality-life-carers-people-type-2-diabetes-literature-review / (accessed on 20 October 2021).

34. Gerbo, R.M.; Jin, C.F.; Clark, K. Diabetes in the Workplace: The Hazards of Hypoglycemia. Curr. Diabetes Rep. 2019, 19, 119. [CrossRef] [PubMed]

35. Smith, K.J.; Deschênes, S.S.; Schmitz, N. Investigating the longitudinal association between diabetes and anxiety: A systematic review and meta-analysis. Diabet. Med. 2018, 35, 677-693. [CrossRef] [PubMed]

36. Imbroll, C.; Cassar, M. Living with Diabetes in the Workplace. DiabetesontheNet. Available online: https://diabetesonthenet. com/Journal-diabetes-nursing/living-diabetes-workplace/ (accessed on 5 July 2021).

37. Nexø, M.A.; Pedersen, J.; Cleal, B.; Bjorner, J.B. Increased risk of long-term sickness absence, lower rate of return to work and higher risk of disability pension among people with type 1 and type 2 diabetes mellitus: A Danish retrospective cohort study with up to 17 years' follow-up. Diabet. Med. 2020, 37, 1861-1865. [CrossRef]

38. Ervasti, J.; Virtanen, M.; Pentti, J.; Lallukka, T.; Tinghög, P.; Kjeldgård, L.; Mittendorfer-Rutz, E.; Alexanderson, K. Work Disability Before and After Diabetes Diagnosis: A Nationwide Population-Based Register Study in Sweden. Am. J. Public Health 2015, 105, e22-e29. [CrossRef] [PubMed]

39. Ervasti, J.; Kivimaki, M.; Dray-Spira, R.; Head, J.; Goldberg, M.; Pentti, J.; Jokela, M.; Vahtera, J.; Zins, M.; Virtanen, M. Psychosocial factors associated with work disability in men and women with diabetes: A pooled analysis of three occupational cohort studies. Diabet. Med. 2015, 33, 208-217. [CrossRef]

40. McCarthy, M.; Vorderstrasse, A.; Yan, J.; Portillo, A.; Dickson, V.V. Managing Diabetes in the Workplace. Workplace Health Saf. 2021, 69, 216-223. [CrossRef] [PubMed]

41. Lix, L.M.; Osman, B.A.; Adachi, J.D.; Towheed, T.; Hopman, W.; Davison, K.S.; Leslie, W.D. Measurement equivalence of the SF-36 in the Canadian multicentre osteoporosis study. Health Qual. Life Outcomes 2012, 10, 29. [CrossRef] [PubMed] 